\title{
Development the Wide Ridges Machine for Laying Drip Irrigation Tubes and Plastic Mulch in Ras Sudr-South of Sinai
}

\author{
Adil Abdelsamia Meselhy \\ Agricultural Mechanization Unit, Soil and Water Conservation Department - Desert Research Center, Cairo, Egypt \\ Email address: \\ adil_meselhy@yahoo.com \\ To cite this article: \\ Adil Abdelsamia Meselhy, Development the Wide Ridges Machine for Laying Drip Irrigation Tubes and Plastic Mulch in Ras Sudr-South of \\ Sinai. International Journal of Applied Agricultural Sciences. Vol. 6, No. 5, 2020, pp. 135-147. doi: 10.11648/j.ijaas.20200605.15
}

Received: September 12, 2020; Accepted: September 25, 2020; Published: October 13, 2020

\begin{abstract}
Mulching facilitates more retention of soil moisture and helps in control of temperature fluctuations, improves physical, chemical and biological properties of soil. As, it adds nutrients to the soil and ultimately enhances the growth and yield of crops. The desired outcomes from raised-bed (wide ridge) are to: drain, aerate, prevent water logging, increase root growth, thereby reinforce the loose structure, increase soil organic matter, increase plant water use, reduce deep drainage and increase production. Therefore, a mulching machine was designed and manufactured to suit different dimensions of chilli raised-beds in Egypt in agriculture. The traditional machine using to build the wide ridges (raised-beds) was developed to suitable for installing raised-bed, cover it with plastic films and laying the drip irrigation pipes (surface and subsurface) at the same time. The developed part consists of main frame, plastic roll carrier unit, drip irrigation pipes roll carrier unit, press wheel assembly, soil covering unit, bed former and three hitching points. The developed machine has overall dimensions $2600 \mathrm{x} 2000$ x $1250 \mathrm{~mm}(\mathrm{~L} \mathrm{x} \mathrm{W} \mathrm{x} \mathrm{H)}$. The weight of the developed plastic mulch-laying machine is $322 \mathrm{~kg}$ (without plastic mulch roll and drip pipes roll). The total fabrication cost of the mulch machine was 20000 LE with 2019 price level. The developed machine was evaluated in Ras-Sudr research station, south Sinai governorate on calcareous sandy loam soil at three different speeds of operation $(2,3$ and $4 \mathrm{~km} / \mathrm{h}$ ), two different methods to use plastic mulch (with and without) and two different methods to lay the drip irrigation pipes (surface and subsurface). The effect of study treatments on actual field capacity, field efficiency, pulling force, fuel consumption rate, total water stored, water consumptive use, water application efficiency, width and thickness of soil cover, width and height of raised-bed, mulching efficiency, chilli yield, productivity of irrigation water, soil salinity, cost of developed machine and cost for manual process were studied. From this study, it was concluded that using developed machine for installing raised-bed and laying both plastic mulch and drip irrigation pipes (surface and subsurface) at the same time. Led to a $68 \%$ decrease in costs compared to the manual method of using the machine before development to install the raised-bed, then laying both plastic mulch and drip irrigation pipes (surface and subsurface) manually. The results of evaluation experiment for the developed machine showed that although at low speed $2 \mathrm{~km} / \mathrm{h}$, the actual field capacity decreased and costs increased by an average of $44 \%$ and $62 \%$, respectively, compared to the speed of $4 \mathrm{~km} / \mathrm{h}$. However, at a speed of $2 \mathrm{~km} / \mathrm{h}$, the pulling force, fuel consumption rate and soil salinity decreased about $14 \%, 15 \%$ and $14 \%$ respectively and field efficiency, total water stored, water consumptive use, water application efficiency, chilli yield and productivity of irrigation water about $4 \%, 6 \%, 4 \%, 16 \%$ and $15 \%$ respectively compared to the speed of $4 \mathrm{~km} / \mathrm{h}$. The results also showed that at a speed of $2 \mathrm{~km} / \mathrm{h}$, the width and thickness of the soil cover of the plastic edges increased about $74 \%$ and $98 \%$, respectively, and the width and height of the raised-bed increased about $23 \%$ and $20 \%$, respectively, compared to the speed of $4 \mathrm{~km} / \mathrm{h}$. The highest mulching efficiency $97 \%$ was achieved at a speed of $2 \mathrm{~km} / \mathrm{h}$ and when laying drip irrigation pipes sub-surface compared to $66 \%$ at speed of $4 \mathrm{~km} / \mathrm{h}$ and laying drip irrigation pipes on soil surface. Therefore, the study recommends using the developed machine to install a raised-bed and laying both of plastic mulch on its surface and drip irrigation pipes sub-surface at a speed of $2 \mathrm{~km} / \mathrm{h}$ achieved the highest efficiency in implementing this system at the lowest cost. Also, worked to increase the irrigation use efficiency, reduced soil salinity and increased yield of chilli crop.
\end{abstract}

Keywords: Chilli Crop, Surface and Subsurface Drip Irrigation, Moisture Conservation, Raised-bed Mulching Machine 


\section{Introduction}

The technology and practice of using plastics to improve crop yield is a relatively new science commonly referred to as plasticulture. Plastics are man-made long chain polymeric molecules [1]. The word plastic comes from the Greek word "plastikos", which means 'able to be molded into different shapes [2]. Mulch is a covering placed over the soil around the plants. Plastic mulch on the surface of the soil causes change in the microclimate on its vicinity. This results in moisture conservation, less soil compaction and higher $\mathrm{CO}_{2}$ levels around plants [3]. A significant increase in yield of cantaloupes when grown with plastic mulch and subsurface drip irrigation. A combination of subsurface drip irrigation and plastic mulch can lead to a significant water savings [4]. Mulch is any biodegradable material placed on a surface of soil for the purpose of reducing evaporation, suppressing weed growth, reducing soil erosion, retaining moisture, and providing plant nutrients as the material decomposes. The result is that plastic mulch film is the primary choice for agricultural application. Plastic mulch film is widely used on high value crops, such as Tomatoes, Melons, and Strawberries increasingly on lower value crops such as corn and chilli. For arable soils, the most effective conservation practices for reducing water loss through surface evaporation are those that provide some degree of surface cover for the soil [5]. Mulching stimulates the microbial activity in soil through improvement of soil agro-physical properties [6]. Mulching also minimizes the use of $\mathrm{N}$ fertilizer [7], warms the soil [8], improves the soil physical condition [9], and suppresses weed growth [10] and could account for increased yield [11]. Mulching has many advantages: mulches are known to buffer soil temperature [12], prevent soil water loss by evaporation [13], inhibit weed germination, and suppress weed growth [14]. Further, they can protect soils from wind-, water-, and traffic-induced erosion and compaction [15]. Finally, mulch can improve crop production by enhancing soil quality by conserving soil moisture, enhancing soil biological activities, and improving the chemical and physical properties of soil [16]. The main benefits of mulching are early crop production, higher yields, better product quality, more efficient water use, reduced leaching of fertilizers, reduced soil and wind erosion, reduced herbicide application for weed control, and others related to pest and disease management [17]. The effect of plastic mulch on growth and yield of chilli (Capsicum annum L.) studied. Plastic mulches used in this study and bare soil was as a control. Plastic mulch generated higher soil temperature and soil moisture under mulch over the control. Plastic mulch encouraged weed population, which were suppressed under plastic. Mulching increased the number of fruits per plant and yield [18]. Mulching is an effective method of manipulating the cropgrowing environment to increase crop yield and improve product quality by controlling soil temperature, retaining soil moisture and reducing soil evaporation [19]. Maximized use of store soil water, increased biomass productivity per unit water use and highest productivity into economic yield under limited water conditions are the principal goals of drought research [20]. Mulching increases soil temperature, maintains soil moisture, improves water and fertilizer absorption, reduces weed growth, and most importantly keeps produce high quality until harvesting to avoid fruits direct contact to the soil [21]. Mulching helps to conserve soil moisture content, also it modifies physical environment of soil, which helps in appropriate growth of crops [22]. The drip irrigation adoption increases of water use efficiency $(60-200 \%)$, saves water (20-60\%), reduces fertilization requirement (20-30\%) through fertigation, produces better quality crop and increases yield (7-25\%) as compared with conventional irrigation [23]. Surface soil mulching has useful effect on soil temperature and moisture and decreasing of the damaging effects of salinity water and soil resources [24]. Globally, over $80000 \mathrm{~km}^{2}$ of arable land is covered every year by plastic mulch films. Using plastic mulch films, farmers are capable to improve the amount, the yield quality, decreasing the use of pesticides, fertilizers and irrigation water. Plastic mulch films are made predominantly from polyethylene [25]. Results from using mulch-laying machine for laying of plastic mulch on raisedbeds indicated that labour saving from 81 to $92 \%$ and saving in irrigation water in range of 25 to $30 \%$ [26]. An experiment conducted to know the effect of plastic mulch, and drip irrigation in chilli on open field condition. The results under this study showed that the polyethylene mulch was significantly superior cover for obtaining high yield and good quality of fruit compared to without mulch [27]. Drip is an irrigation technology known to increase the control of water application and offers several advantages to growers. It reduces soil evaporation and weed population, increases plant transpiration, and when well-managed, excessive water drainage is unlikely to occur, thus allowing nutrients to be retained in the root zone for prolonged periods [28]. Plastic films are laid before crop planting or transplanting. This includes preparation of seedbed, spread mulch film and anchoring of edges of film. Raised seedbed has to be prepared for plastic mulching. Two persons are required for laying the plastic over the soil bed, while one more person behind them to shovel the soil onto the edges of the mulch. These operations when done by manually become very time consuming, labour intensive, tedious and costly. Manual method is economical for the small fields but not economical for the large fields [29]. The use of plastic mulch in agriculture has been increased dramatically in the last 10 years throughout the world. This increase is due to the benefits such as increase in soil temperature, effective weed management, moisture conservation, reduction of certain insect pest, high crop yield, less crop contamination, less soil compaction and improved germination rate and more efficient use of soil nutrients 
[30]. Manual mulch laying process is characterized with poor quality of work, disturbance of mulch sheet due to wind, labour intensive, mulch sheet getting torn down during handling and difficulty in covering of mulch sheet. Presently, six manual labours are required for laying plastic mulch sheet [31]. Plastic mulch increases soil temperature and maintains soil moisture, so it alters the exchange of matter and energy between the land surface and the atmosphere including the following aspects: (i) Plastic mulch can alter surface roughness, leading to more incoming sunlight reflected back to the atmosphere, and increased temperature of the atmosphere. (ii) Plastic mulch can prevent water to evaporate, thus altering water cycles. (iii) Plastic mulch and its inner surface with dew can block the emission of longwave radiation, increasing the temperature of the soil. (iv) Plastic mulch can block gas, such as $\mathrm{N} 2 \mathrm{O}, \mathrm{CO} 2$, and $\mathrm{CH} 4$, the exchange between soil and atmosphere [32]. Moreover, plastic mulch can influence the residual rate of soil organic materials in the soil, inevitably affecting soil microbial and soil ecosystems [33]. Plastic mulch is playing an increasingly important role in modern agriculture. On one hand, the widespread use of plastic mulch has significantly increased crop yield, which is of great significance for food security [34]. Mulching is process of covering the soil round the plant root area with a view to insulate the plant and its roots from the consequences of utmost temperature fluctuation. Mulching will create a microclimate for the plant, which fitted to simplest performance by regulating soil water, soil temperature, humidity, $\mathrm{CO}_{2}$ enrichment and increased microbial activity in the soil. Mulches can be classified into organic and inorganic (plastic mulch). (1) Organic: Organic materials such as crop residue by-product, farm yard manure and byproduct of timber industry is used for organic mulching. (2) Inorganic: materials such as plastic films known as inorganic mulches. Plastic mulches can be made available in different colors and thickness to obtain desired result. Organic mulch always does not provide sufficient weed control; they may also carry weed seeds and repeatedly slow down the soil warming. Especially in spring season, it will cause delay of plant growth. Weed rate cannot be controlled in organic method, by employing plastic it will reduce the weed waste on labor to clean the farm. It is documented that plastic film increases the yields of the many crops by inhibiting weeds growth and increasing soil temperature and moisture also reducing pest infestations. The use of plastic mulch has also become a standard practice for many farmers to control weeds [35]. Raised-bed (wide ridge) defines as a soil raised above the surrounding ground level (approximately $15-50 \mathrm{~cm}$ height) in which the soil is formed in $(70-120 \mathrm{~cm}$ wide) beds, which can be of any length or shape. The desired outcomes from this management are to: drain, aerate, prevent water logging, increase root growth, thereby reinforce the loose structure, increase soil organic matter, increase plant water use, reduce deep drainage and increase production [36]. Raised bed technology showed less lodging as compared to flat sowing as well as $11.2 \%$ increase in grain yield along with $40-50 \%$ saving in irrigation water. The experiment also revealed that the raised bed planting method may be less susceptible to adversities of climate change because it portrays better ability to plant roots anchorage on beds and ability to withstand water stress [37]. Raised beds are reportedly saving $25-30 \%$ irrigation water and increasing water use efficiency [38]. Raised-bed providing better opportunities to leach salts from the furrows. However, under saline conditions [39].

Therefore, the aims of this research are development the wide ridge machine for installing raised-bed in Egypt conditions to lay plastic mulch firmly and equipped with a special unit for laying the drip irrigation pipes (surface and subsurface) underneath the plastic film at the same time. In addition, conducting a field experiment to evaluate the performance of the developed machine at different forward speeds and study its effect on soil moisture and chilli yield.

\section{Materials and Methods}

This study was carried out at ras-sudr research station, south of Sinai governorate (latitude: $29^{\circ} 37^{\prime} 26^{\prime \prime} \mathrm{N}$, longitude: $32^{\circ} 42^{\prime} 43^{\prime \prime} \mathrm{E}$ and the elevation from sea surface $=36.2 \mathrm{~m}$ ), on calcareous sandy loam soil. This soil suffers from the problem of soil, and irrigation water salinity where, salts in the soil-water solution decrease the amount of water available for plant uptake. Maintaining a higher soil-water content with more frequent irrigations relieves the effect of salt on plant moisture stress. The field experiment was carried out from July 2019 to January 2020 with an experimental area of about one hectare. Which irrigated by drip irrigation system. Before the soil preparation directly, the average moisture content of soil surface layer $(0-30 \mathrm{~cm})$ was determined and found to be $19 \%$ (d.b.). Some physical and chemical properties of the soil and well irrigation water were measured and presented in Table 1.

Table 1. Soil physical and chemical properties.

\begin{tabular}{ll}
\hline Soil parameters & Value \\
\hline Sand, Percent & 69.5 \\
Silt, Percent & 20.5 \\
Clay, Percent & 10.1 \\
Textural class & Sandy Loam soil \\
Bulk Density, g/cm ${ }^{3}$ & 1.24 \\
Field Capacity, Percent & 24.5 \\
Permanent Wilting Point, Percent & 12.6 \\
Infiltration Rate cm/h & 5.67 \\
CaCO, Percent & 44.3 \\
O. $\mathrm{M}$, Percent & 0.56 \\
Soil pH & 7.56 \\
Irrigation water $\mathrm{pH}$ & 7.87 \\
Soil E. C, ds $/ \mathrm{m}$ & 13.64 \\
Irrigation water E. C, ds $/ \mathrm{m}$ & 4.17 \\
\hline
\end{tabular}

\subsection{The Specifications of Fabricated Machine}

This research aims to develop a machine for former raisedbeds to laying plastic mulch on its surface, as well as laying lateral drip irrigation pipes on the surface of the raised-beds 
or burying it subsurface with the required depths.

\subsection{Wide Ridges (Raised-bed) Machine}

This machine used for installing the wide ridges (raised-bed) at the different shape and dimensions of section area required (width $\mathrm{x}$ height). The machine has overall dimensions $1300 \mathrm{x}$ $1450 \times 1250 \mathrm{~mm}$ (Length $\times$ Width $\times$ Height). Consisted of border box and three hitch points as shown in Figure 1.

\subsection{Constructional Details of Development Wide Ridges \\ Machine for Laying Both GR Pipes (Surface and Subsurface) and Plastic Mulch}

The wide ridge machine used to install raised-bed, which, was developed to cover raised-bed with plastic mulch, and laying the drip irrigation pipes (surface and subsurface) at the same time. The constructional details of developed machine discussed as the following:

\subsubsection{Main Frame}

The main frame was made up of M. S. Square pipe of $(50 \mathrm{x}$ 50) $\mathrm{mm}$ section. The overall dimensions of the main frame were $1300 \mathrm{~mm}$ in length, $2000 \mathrm{~mm}$ in width and $620 \mathrm{~mm}$ above the ground level. All parts of machine like, press wheel assembly; plastic roll carrier unit, drip irrigation pipes roll carrier unit and soil-covering unit were mounted on the main frame by welding or by using nuts and bolts. This developed part attachment with the wide ridge machine to component one unit using to gathers the soil from the sides and forms a raisedbed in dimensions (900 mm width and $300 \mathrm{~mm}$ height), covering raised-bed with plastic mulch and laying drip irrigation pipes (surface and subsurface) at the same time. The dimensions and parts of developed machine presented in Figure 2. Also, Figure 3 shows the machine during operation.

\subsubsection{Plastic Roll Carrier Unit}

The plastic roll has to be carried by a horizontal M. S. shaft perpendicular to direction of travel provided. A shaft was mounted in between the two bearing, which is used to roll the plastic film. The shaft was supported on the main frame. The plastic sheet has to be placed under the press wheel manually before starting of the plastic mulch laying operation. The mulch film rotated and started to unwound automatically when the machine moves forward and mulch film was laid on the bed as shown in Figure 4. The plastic mulch used is of size 400 $\mathrm{m}$ length, $1.8 \mathrm{~m}$ width and 50-micron thickness.

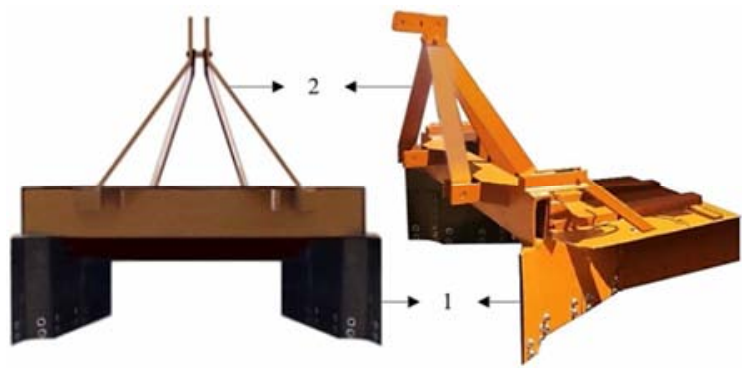

Figure 1. Wide ridges machine consisted of, 1- border box and 2- three hitch points.

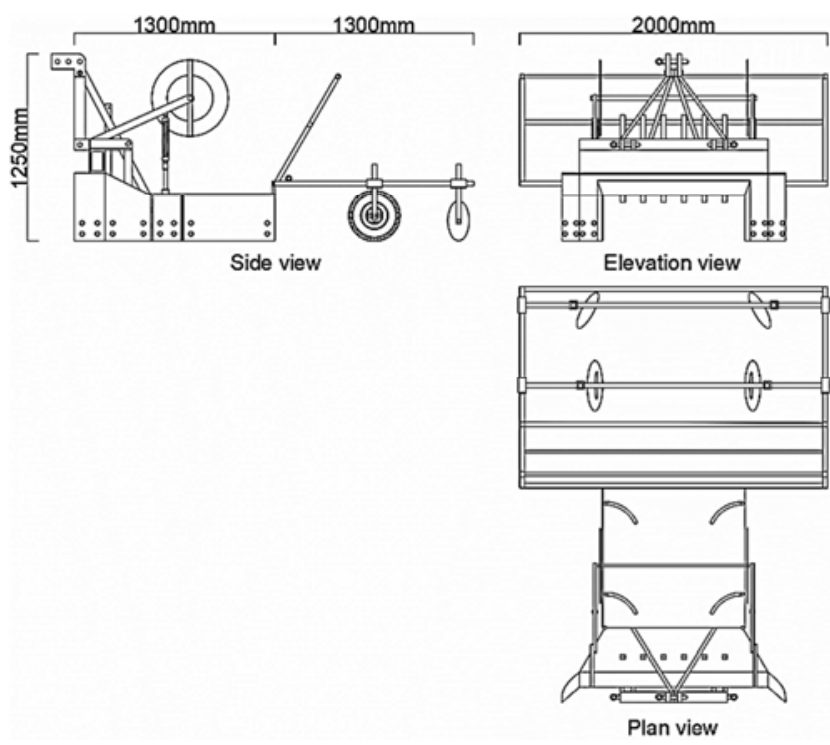

Figure 2. Schematic diagram of the developed raised-beds mulching machine.

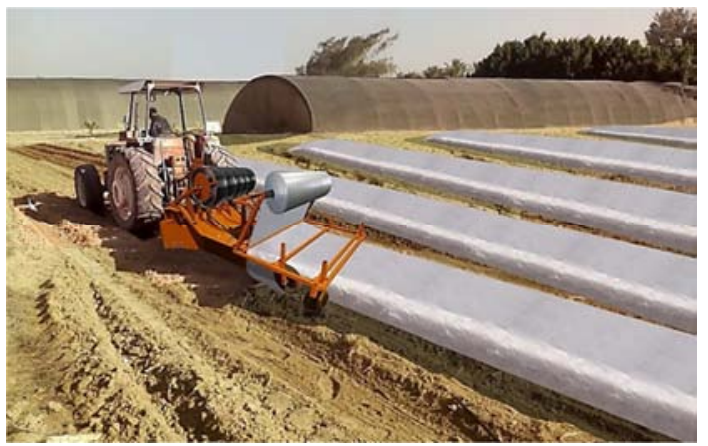

Figure 3. Developed mulching machine during the field experimental work.

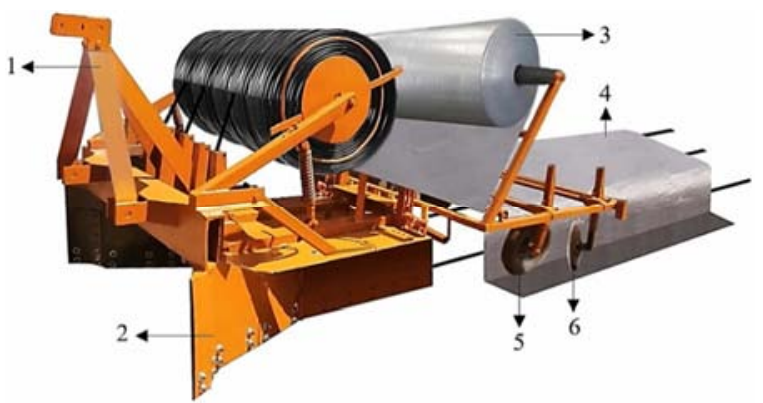

Figure 4. Laying both of plastic mulch on raised-bed and subsurface drip irrigation pipes. 1- Three hitch points, 2-Raised-bed former, 3-Plastic roll carrier unit, 4- Plastic mulch laid on raised-bed, 5-Press wheel, 6- Soil covering unit.

\subsubsection{Press Wheel}

The operation of press wheel is to stretch the laid plastic mulch film on bed so that it will not get displaced while in operation. The height of the press wheel is adjustable.

\subsubsection{Soil Covering Unit}

Soil covering unit as attached to the frame for lifting, turning and throwing the soil over the plastic mulch at the side edges. Two concave discs have been used as soil covering unit. The depth of operation of the soil covering 
device is adjustable.

\subsubsection{Drip Irrigation Pipes Roll Carrier Unit}

The drip irrigation pipes roll has to be carried by a horizontal M. S. shaft perpendicular to direction of travel provided. A shaft was mounted in between the two bearing which is used to roll the drip pipes irrigation. The shaft was supported on the wide ridge unit. The drip pipes have to be placed under dead weight manually before starting of the drip pipes laying operation. The drip pipes rotated and started to unwound automatically when the machine moves forward and drip pipes was laid on the bed and under the plastic film (surface) or under soil surface at depth of $15 \mathrm{~cm}$ (subsurface) as shown in Figures 5 and 6.

\subsection{Tractor}

A $90 \mathrm{hp}$ at $2200 \mathrm{rpm}$ tractor BELARUS diesel engine was used during experiment. The tractor Model, D-243.1. Power take-off shaft 540-1000 rpm. Tractor weight $3460 \mathrm{~kg}$. Tires front $20 \times 9.5$ and rear $38 \times 15.5$. Distance between wheels (1350-1850 mm front wheel and 1450-2200 mm rear wheel). The tractor has 18 forward speed and 4 reverse speed.

\subsection{Experimental Design}

The experimental area was about of one hectare. This experiment was established as split-split plots in three replicates, divided into main plot involved three levels of operation speed (2, 3 and $4 \mathrm{~km} / \mathrm{h}$ ). Each main plot includes sub-plots, which involved two methods for using plastic mulch (with and without). Each sub-plot includes sub-sub plots, which involved two methods for laying drip irrigation pipes (surface and subsurface). Experimental details presented in Table 2 .
Table 2. Experimental Details.

\begin{tabular}{ll}
\hline Particulars & Specification \\
\hline Name of the crop & Chili \\
Scientific name & Capsicum annum L. \\
Variety & Jayanti \\
Planting time & Autumn season \\
Design & Split-Split plot \\
Number of treatments & 12 \\
Number of replications & 3 \\
Crop spacing & $30 \mathrm{~cm}$ x 45 cm \\
Duration of crop & 175 Days \\
Mulch & Silver polyethylene mulch of $50 \mu \mathrm{m}$ \\
Date of transplanting & 27 July 2019 \\
Date of harvesting & 19 September 2019 to 17 January 2020 \\
\hline
\end{tabular}

\subsection{Irrigation System}

Irrigation system in this study was drip irrigation (surface and subsurface). Three drip irrigation pipes were laying on each raised-bed as shown in Figure 7, which irrigates three rows of chilli plants. Geometry with dripper to dripper spacing of $45 \mathrm{~cm}$.

\subsection{Crop Water Requirement}

Crop water requirement was calculated using the reference evapotranspiration $\left(\mathrm{ET}_{\mathrm{o}}\right)$ and the crop coefficients $\left(\mathrm{K}_{\mathrm{C}}\right)$ by the following equation:

$$
\mathrm{ETc}=\mathrm{ET}_{\mathrm{o}} * \mathrm{~K}_{\mathrm{C}}
$$

Where; $\quad \mathrm{ET}_{\mathrm{c}}=\mathrm{Crop} \quad$ Evapotranspiration $\quad(\mathrm{mm} /$ day $)$, $\mathrm{ET}_{\mathrm{o}}=$ Reference Evapotranspiration $(\mathrm{mm} /$ day) and $\mathrm{Kc}=\mathrm{Crop}$ coefficients.

Represent the Reference Evapotranspiration $\left(\mathrm{ET}_{\mathrm{o}}\right)$ according to (Center Laboratory for Agricultural Climate, CLAC.), the average crop coefficients (Kc) for Chilli according to Andreas P. (2002) [40] as shown in Table 3.

Table 3. Growth stages, Reference evapotranspiration, crop coefficient and Crop Evapotranspiration of Chilli crop.

\begin{tabular}{llllll}
\hline Growth stage & Duration day & ETo, mm/day & $\mathbf{K}_{\mathbf{c}}$ & ETc, mm/day & Depth of water, mm \\
\hline Initial & 20 & 4.6 & 0.48 & 2.2 & 44 \\
Dev. & 40 & 4.3 & 0.74 & 3.1 & 124 \\
Mid-season & 90 & 3.2 & 1.01 & 3.2 & 288 \\
Season end & 25 & 2 & 0.7 & 1.4 & 9.9 \\
Total & 175 & 14.1 & 2.93 & 45 \\
\hline
\end{tabular}

Net irrigation requirement $\left(\mathrm{IR}_{\mathrm{n}}\right)$ is derived from the field balance equation:

$$
\mathrm{IR}_{\mathrm{n}}=\mathrm{ET}_{\mathrm{c}}-\mathrm{P}_{\mathrm{eff}}+\mathrm{LR}
$$

Where: $\mathrm{IR}_{\mathrm{n}}=\mathrm{Net}$ irrigation requirement $(\mathrm{mm} /$ day $), \mathrm{ET}_{\mathrm{c}}$ : Crop evapotranspiration ( $\mathrm{mm} /$ day), $\mathrm{P}_{\text {eff }}=$ Effective dependable rainfall, $(\mathrm{mm} /$ day) and $\mathrm{LR}=$ Leaching requirement $(\mathrm{mm})$.

Gross irrigation requirements account for losses of water incurred during conveyance and application to the field.

$$
\mathrm{IR}_{\mathrm{g}}=\mathrm{IR}_{\mathrm{n}} / \mathrm{E}_{\mathrm{a}}
$$

Where: $\operatorname{IR}_{\mathrm{g}}=$ Gross irrigation requirements $(\mathrm{mm} /$ day $)$, $\mathrm{IR}_{\mathrm{n}}=\mathrm{Net}$ irrigation requirement $\left(\mathrm{mm} /\right.$ day) and $\mathrm{E}_{\mathrm{a}}=$ Overall irrigation efficiency (\%).
Therefore, total water applied with leaching requirement for chilli crop at drip irrigation system was $6372 \mathrm{~m}^{3} / \mathrm{ha}$.

\subsection{Use of Polyethylene Mulch in the Experiment}

In order to maximize water use efficiency by the plant to improve the quality green chilli, the use of mulch becomes an important cultural practice in many regions for the commercial production of vegetable crop. A silver polyethylene mulch of $50-\mu \mathrm{m}$ thickness (UV- protected) was spread over the raisedbed. Two sides of mulch were buried under the soil. After installing raised-bed and covering it with plastic mulch and laying drip irrigation pipes, plants were transplanted using manual transplanter as shown in Figure 8. 


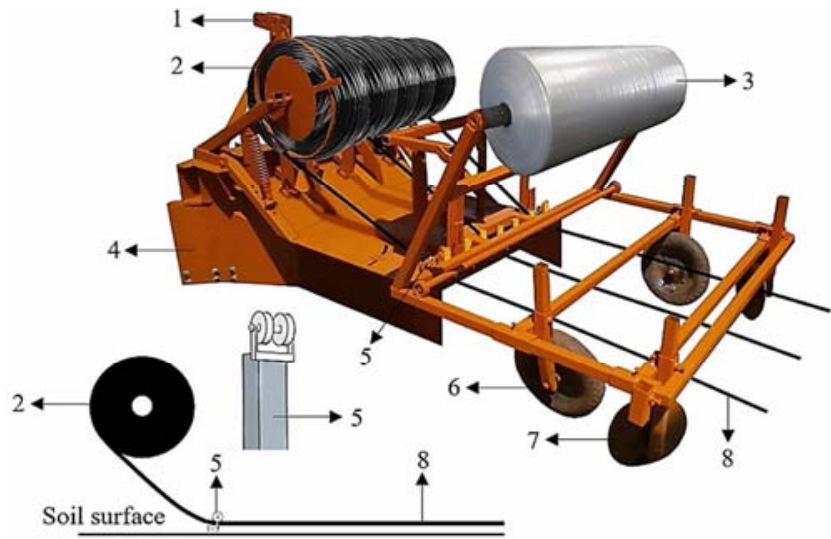

Figure 5. Laying of drip irrigation pipes on surface of raised-bed under plastic mulch. 1- Three hitch points, 2- Drip irrigation pipes roll carrier unit, 3-Plastic roll carrier unit, 4-Raised-bed former, 5-Roller, (6) Press wheel, 7- Soil covering unit, 8-drip pipes on raised-bed surface.

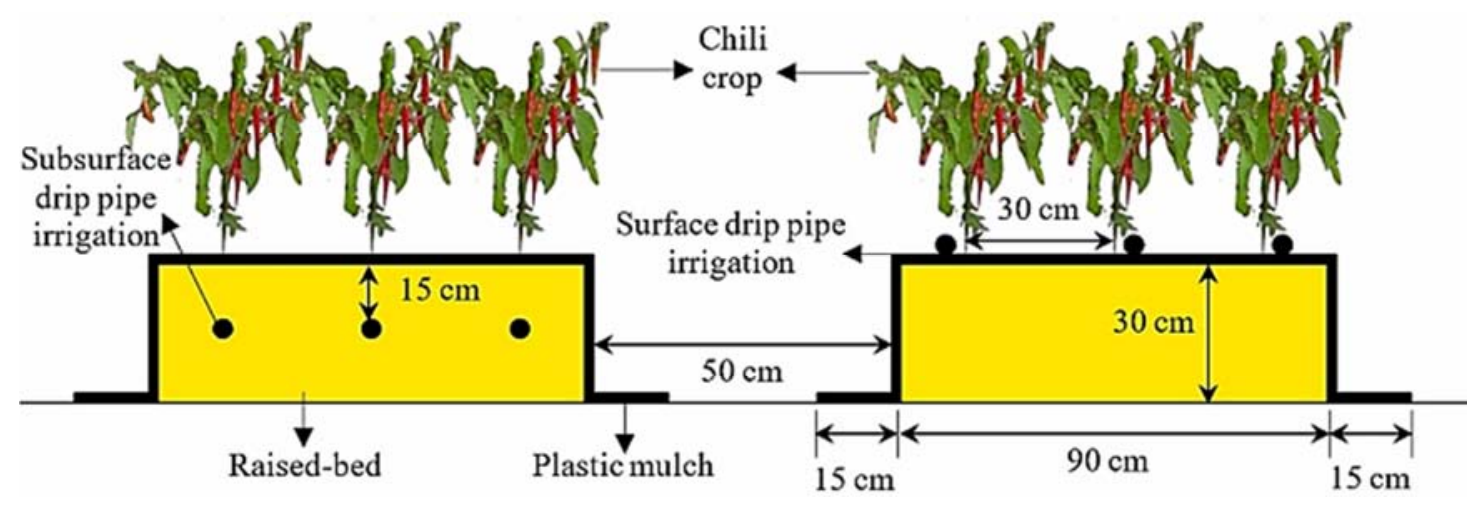

Figure 7. Dimensions of raised-bed with plastic mulch and position of drip irrigation pipes (surface and subsurface).

\subsection{Transplanting of Seedlings}

Chilli seedlings (Jayanti) were transplanted using manual transplanter as shown in Figure 8 in three rows with spacing of $30 \mathrm{~cm} \mathrm{x} 45 \mathrm{~cm}$ on raised-bed of $90 \mathrm{~cm}$ width having three laterals. Transplanting was carried out on $27^{\text {th }}$ of July 2019.

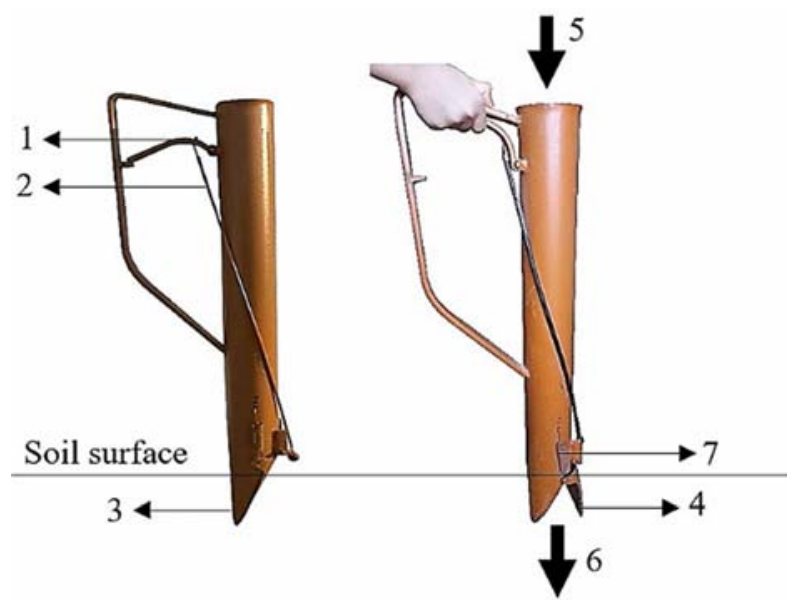

Figure 8. Manual transplanter. 1-Arm to open transplanter mouth, 2- Wire, 3- Transplanter mouth closed, 4- Transplanter mouth is open, 5-Enter the transplant, 6- Exit the transplant, 7- Spring.

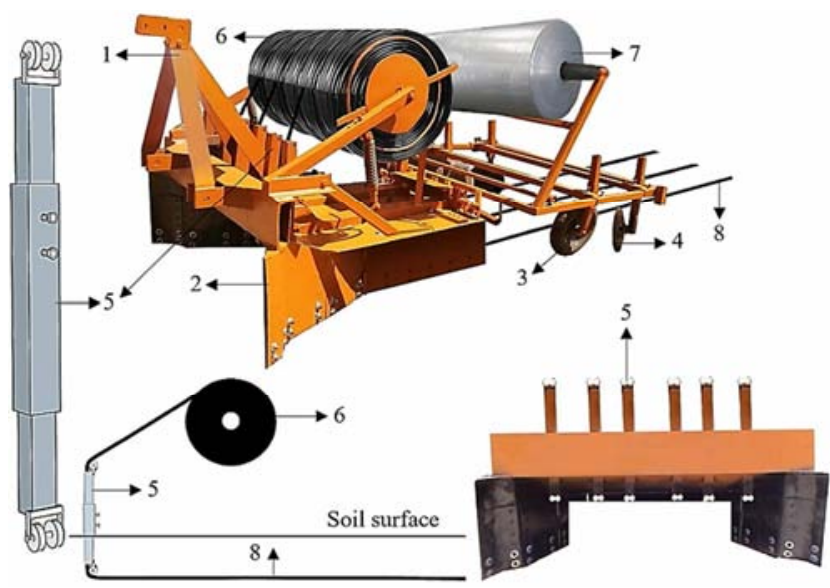

Figure 6. Laying of drip irrigation pipes under soil surface (subsurface at depth 15cm) of raised-bed. 1- Three hitch points, 2-Raised-bed former, 3Press wheel, 4-Soil covering unit, 5- Unit to control the depth of drip pipes, 6- drip pipes irrigation roll carrier unit, 7-Plastic roll carrier unit, 8-drip pipes under raised-bed surface.

\subsection{Measurements}

\subsubsection{Theoretical Field Capacity, Actual Field Capacity and Field Efficiency}

Theoretical field capacity, actual field capacity and field efficiency were calculated by using equations mentioned by kepner et al. (1978) [41].

\subsubsection{Pulling Force}

Pulling force for machine was measured by hydraulic dynamometer, which was, coupled between the two tractors with the attaching machine to estimate its draught force. A considerable number of readings taken at a time interval 10 seconds to obtain an accurate average of draught force.

\subsubsection{Fuel Consumption Rate}

Fuel consumption per unit time was determined by measuring the volume of fuel consumed during operation time. It was measured using the fuel meter equipment as shown in Figure 9 the length of line which marked by the marker tool on the paper sheet represents the fuel consumption. The fuel meter was calibrated prior and the volume of fuel was determined accurately. 


\subsubsection{Soil Moisture Content and Soil Salinity}

Soil moisture content in $0-60 \mathrm{~cm}$ soil layers at $15 \mathrm{~cm}$ was measured using a TDR 300 soil moisture meter (time domain reflector meter). Soil salinity (Direct soil EC probe).
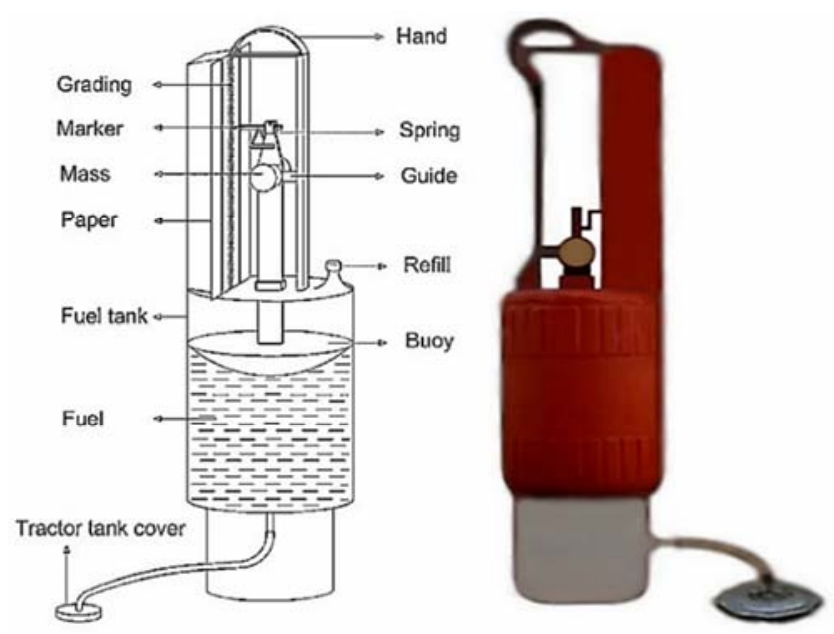

Figure 9. Fuel meter for measuring fuel consumption.

\subsubsection{Total Water Stored in the Effective Root Zone}

Water stored in the root zone was determined according to James (1988) [38] as follows:

$$
\text { TWS }=\sum_{\mathrm{i}=1}^{\mathrm{i}=4}\left(\frac{\theta_{\mathrm{fc}}-\theta_{\mathrm{wp}}}{100}\right) \mathrm{D}_{\mathrm{r}} * \rho_{\mathrm{b}}
$$

where: TWS $=$ Water stored in the root zone, $(\mathrm{mm}), \Theta_{\mathrm{fc}}=$ Soil moisture content at field capacity, $(\%), \Theta_{\mathrm{wp}}=$ Soil moisture content at permanent wilting point, $(\%), \mathrm{D}_{\mathrm{r}}=$ Effective root depth, $(\mathrm{mm}), \rho_{\mathrm{b}}=$ Soil bulk density, $\left(\mathrm{g} / \mathrm{cm}^{3}\right)$ for depth and $\mathrm{i}=$ Number of soil layers (1-4).

\subsubsection{Water Consumptive Use in Effective Root Zone}

Water consumptive use by growing plants was calculated based on soil moisture depletion (SMD) according to Hansen et al. (1979) [43].

$$
\mathrm{WCU}=\sum_{\mathrm{i}=1}^{\mathrm{i}=4}\left(\frac{\theta_{\mathrm{fc}}-\theta_{\mathrm{i}}}{100}\right) \mathrm{D}_{\mathrm{r}} * \rho_{\mathrm{b}}
$$

Where: WCU $=$ Water consumptive use in the effective root zone $(\mathrm{mm}), \Theta_{\mathrm{fc}}=$ Soil moisture content at field capacity, (\%), $\Theta_{i}=$ Soil moisture content before next irrigation, (\%), $\mathrm{D}_{\mathrm{r}}=$ Effective root depth, $(\mathrm{mm}), \rho_{\mathrm{b}}=$ Soil bulk density, $\left(\mathrm{g} / \mathrm{cm}^{3}\right)$ for depth and $\mathrm{i}=$ Number of soil layers (1-4).

\subsubsection{Water Application Efficiency}

Water application efficiency was calculated according to Israelsen and Hansen (1962) [44] as follows:

$$
\mathrm{WAE}=\left(\frac{\mathrm{TWS}}{\mathrm{TWA}}\right) * 100
$$

Where: WAE=Water application efficiency (\%), TWS=Total water stored in the effective root zone $\left(\mathrm{m}^{3} / \mathrm{ha}\right)$ and TWA $=$ Total water applied $\left(\mathrm{m}^{3} / \mathrm{ha}\right)$.

\subsubsection{Productivity of Irrigation Water}

Productivity of irrigation water (PIW) was calculated according to Ali et al. (2007) [45] as $\mathrm{kg}$ yield $/ \mathrm{m}^{3}$ water applied.

$$
\mathrm{PIW}=\frac{\mathrm{Y}}{\mathrm{I}}
$$

Where: $\mathrm{Y}=$ Chilli crop yield $(\mathrm{kg} / \mathrm{ha})$ and $\mathrm{I}=$ Irrigation water applied $\mathrm{m}^{3} /$ ha.

\subsubsection{Evaluation of Plastic Mulching Process}

\section{(i). Mulching Efficiency}

The mulching performance was evaluated by observing the plastic mulching film through, the length of correct covered mulching film edges, un-covered mulching film edges, injuries in mulching film and air pockets underneath the mulching film in each treatment. During the experimental work, the performance of mulching machine was assessed by taking randomly selected $10 \mathrm{~m}$ length of covered raised beds as the following experimental formula:

$$
\text { Mulching efficiency }(\eta m)=100-(R u+R i+R p)
$$

Where: $\mathrm{Ru}=$ The percentage of the un-covered mulched film edge length in $10 \mathrm{~m}(\%), \mathrm{Ri}=$ The percentage of the injured mulched film in10 length $\mathrm{m}(\%)$ and $\mathrm{Rp}=$ The percentage of the air pockets under the film in length of $10 \mathrm{~m} \mathrm{( \% )}$.

(ii). Width and Thickness of Soil Cover

The width and thickness of soil covered on each side of plastic sheet was measured by using a measuring scale.

(iii). Height and Width of Bed

After the operation of plastic mulch laying by study machine, the height and width of bed formed by the machine was measured at different locations in the field with the help of measuring scale.

\subsubsection{The Cost and Chilli Yield}

(i). Cost Analysis and Economical Evaluation

The cost analysis was calculated according to Oida, (1997) [46]. It was performed in two steps. The first step was to calculate the cost of the materials and fabrication. The second step was to calculate the mulching machine operating cost. In order to evaluate the financial viability of the mulching machine, three parameters computed and analyzed. Also, a comparison between the manual mulching cost and the mechanical mulching cost is conducted. These costs include depreciation (D), annual capital interest taxes (I), housing and insurance cost (THI), repair and maintenance cost $(\mathrm{R})$, fuel cost $(\mathrm{F})$, lubrication cost (Lc), and labor cost (L).

$$
\mathrm{TC}=\frac{[(\mathrm{D})+(\mathrm{L})+(\mathrm{THD})]+[(\mathrm{R})+(\mathrm{F})+(\mathrm{LC})+(\mathrm{L})]}{\mathrm{na}}
$$

Where: $\mathrm{Tc}=$ Total cost for machine or tractor $(\mathrm{LE} / \mathrm{h})$ and $\mathrm{na}=$ Annual working hours $=500(\mathrm{~h} /$ year).

$$
\mathrm{Tc}=\frac{\left[\left(\frac{P c-S v}{\mathrm{Y}}\right)+\left(\frac{P c+S \mathrm{~V}}{2} \times \frac{i}{100}\right)+(0.02 \mathrm{Pc})\right]+\left[\left(\frac{P c \times \mathrm{rc}}{\mathrm{Y}}\right)+(\mathrm{fc} \mathrm{x} \mathrm{fp})+(\mathrm{Lc})+(\mathrm{Ni} \mathrm{x} \mathrm{L} \mathrm{x} \mathrm{n})\right]}{\mathrm{na}}(10)
$$

Where: $\mathrm{Pc}=$ Mulching machine manufacturing price or tractor price (L. E), $\mathrm{Sv}=$ Salvage value $=5 \%$ from the 
mulching machine manufacturing price or tractor price (L. E), $\mathrm{Y}=$ Machine age $=5$ years for machine and 10 years for tractor, $\mathrm{i}=$ Interest $\mathrm{rate}=14 \%, \quad \mathrm{rc}=$ Coefficient of repair and maintenance $=1$ for tractor, 0.6 for the mulching machine, $\mathrm{fc}=$ Actual fuel consumption $=$ measured $\quad(1 / \mathrm{h}), \quad \mathrm{fp}=$ Fuel price $=6.75$ (L. E) $=$ for diesel fuel, $\mathrm{Lc}=$ Lubrication $\cos \mathrm{t}=14 \%$ of fuel cost, $\mathrm{Ni}=\mathrm{Number}$ of labors=Mulching crew (one labor), $\mathrm{L}=$ Labor cost=120 L.E/day, day (7 hours) $(\mathrm{L} . \mathrm{E} / \mathrm{h})$, $\mathrm{n}=$ Annual working days $=(500 / 7)$ and $\mathrm{na}=$ Annual working hours $=500, \mathrm{~h} /$ year.

The cost was calculated also for machine before development at installing raised-bed only after that laying plastic mulch and drip irrigation pipes (surface and subsurface) manually. The manual mulching need seven workers, two workers for spreading the plastic roll on the top of the raised-bed, one worker for filling plastic bags and put them on the top of the roll to prevent it from fly by wind and four workers to buried the side of plastic film edges with soil. The manual laying drip irrigation pipes need two workers for surface pipes and three workers for subsurface. This process needs about an average of 14 hours/hectare ( 7 hours work in day) this means that the one hectare needs two days' work.

(ii). Total Cost Per Unit Area

Total cost per unit area was determined as follows:

$$
\mathrm{TCA}=\frac{\mathrm{C}}{\mathrm{AFC}}
$$

Where: $\quad \mathrm{TCA}=$ Total cost per unit area (L.E/ha), $\mathrm{AFC}=$ Actual field capacity (ha/h) and $\mathrm{C}=$ Hourly cost (L.E/h).

(iii). Chilli Yield

The yield of green chilli from net plot in every treatment was observed in every picking. The total yield of the fruit harvested from net plot was recorded by cumulating yield per picking and expressed in $\mathrm{kg}$ per plot and then it is converted into yield per hectare.

\section{Results and Discussion}

\subsection{Effect of Study Treatments on Actual Field Capacity, Field Efficiency and the Operation Cost}

Data in Table 4 and Figures 10 and 11 showed that actual field capacity (AFC) increased about $43 \%$ and $82 \%$ when operation speed increased from 2 to 3 and $4 \mathrm{~km} / \mathrm{h}$ respectively. In addition, field efficiency (FE) decreased about 5\% and 9\% when operation speed increased from 2 to 3 and $4 \mathrm{~km} / \mathrm{h}$ respectively. This may be due to the fact that, with increase in operation speed both theoretical and actual field capacity will increase. However, rate of increase of AFC is quite less than that of theoretical field capacity. Therefore, FE may decrease with increasing of speed. It was observed that AFC and FE decreased about $6 \%$ and $5 \%$ respectively when laying plastic mulch compared to treatment without laying mulch. Also, AFC and $\mathrm{FE}$ decreased about $4 \%$ and $3 \%$ respectively when laying sub-surface drip irrigation pipes compared to surface laying. This may be due to the fact that, the laying plastic mulch and sub-surface drip irrigation pipes caused decreasing in the distance covered by the machine per unit time as a result, AFC decreased and also field efficiency decreased. On the other hand, Figure 12 showed that the cost of developed machine (CDM) decreased about $25 \%$ and $38 \%$ when operation speed increased from 2 to 3 and $4 \mathrm{~km} / \mathrm{h}$ respectively. And CDM increased about $15 \%$ and $55 \%$ when laying both of plastic mulch and sub-surface drip irrigation pipes respectively compared to without mulching and surface laying drip irrigation pipes. Total cost for laying plastic mulch, laying surface drip irrigation pipes and laying sub-surface drip irrigation pipes manually increased about 312\%, 197\% and $218 \%$ respectively compared to use developed machine at same operation. In general, the total cost for installing raisedbed, laying plastic mulch and laying drip irrigation pipes (surface and sub-surface) increased about 208\% for manual method compared to use developed machine.

Table 4. Effect of study treatments on actual field capacity, field efficiency and the cost.

\begin{tabular}{|c|c|c|c|c|c|c|c|c|c|c|c|}
\hline \multirow{2}{*}{$\mathbf{F S}, \mathbf{k m} / \mathbf{h}$} & \multirow{2}{*}{$\mathbf{P M}$} & \multirow{2}{*}{ GIP } & \multicolumn{3}{|l|}{ AD } & \multicolumn{5}{|l|}{ BD } & \multirow{2}{*}{ CDP, $\%$} \\
\hline & & & AFC & FE & CMT & AFC & FE & CMT & CL & TCM & \\
\hline \multirow{4}{*}{2} & & $\mathrm{~S}$ & 0.226 & 78 & 1002 & \multirow{4}{*}{0.244} & \multirow{4}{*}{84} & \multirow{4}{*}{801} & 2592 & 3393 & 70 \\
\hline & W & SS & 0.22 & 76 & 1056 & & & & 2880 & 3681 & 71 \\
\hline & WO & $\mathrm{S}$ & 0.238 & 82 & 871 & & & & 576 & 1377 & 37 \\
\hline & wo & SS & 0.232 & 80 & 924 & & & & 864 & 1665 & 54 \\
\hline \multirow{4}{*}{3} & W & $\mathrm{S}$ & 0.325 & 74 & 753 & \multirow{4}{*}{0.352} & \multirow{4}{*}{80} & \multirow{4}{*}{575} & 2592 & 3167 & 76 \\
\hline & w & SS & 0.317 & 72 & 793 & & & & 2880 & 3455 & 77 \\
\hline & WO & $\mathrm{S}$ & 0.343 & 78 & 655 & & & & 576 & 1151 & 43 \\
\hline & wo & SS & 0.334 & 76 & 694 & & & & 864 & 1439 & 52 \\
\hline \multirow{4}{*}{4} & & $\mathrm{~S}$ & 0.412 & 71 & 620 & \multirow{4}{*}{0.447} & \multirow{4}{*}{77} & \multirow{4}{*}{472} & 2592 & 3064 & 79 \\
\hline & W & SS & 0.400 & 69 & 655 & & & & 2880 & 3352 & 80 \\
\hline & WO & $\mathrm{S}$ & 0.435 & 75 & 539 & & & & 576 & 1048 & 49 \\
\hline & wu & SS & 0.423 & 73 & 567 & & & & 864 & 1336 & 58 \\
\hline
\end{tabular}

Where: $\mathrm{FS}=$ Forward speed, $\mathrm{km} / \mathrm{h}, \mathrm{PM}=$ Plastic mulch, GIP=Drip irrigation pipes system, $\mathrm{AD}=$ Developed machine for installing raised-bed, laying plastic mulch and laying drip irrigation pipes (surface and subsurface) at the same time, $\mathrm{BD}=$ Machine before development for installing raised-bed only, $\mathrm{CDP}=\mathrm{Cost}$ decreasing percentage of developed machine compared to manual method, $\mathrm{AFC}=$ Actual field capacity, ha/h, FE=Field efficiency, \%, CMT $=$ Cost of machine and tractor, $\mathrm{L} . \mathrm{E} / \mathrm{ha}, \mathrm{CL}=\mathrm{Cost}$ of labors, $\mathrm{L} . \mathrm{E} / \mathrm{ha}, \mathrm{TCM}=$ Total cost for manual process, L.E/ha, $\mathrm{W}=$ with mulching plastic, WO=without mulching plastic, $\mathrm{S}=$ laying surface drip irrigation pipes and $\mathrm{SS}=$ laying sub-surface drip irrigation pipes. 


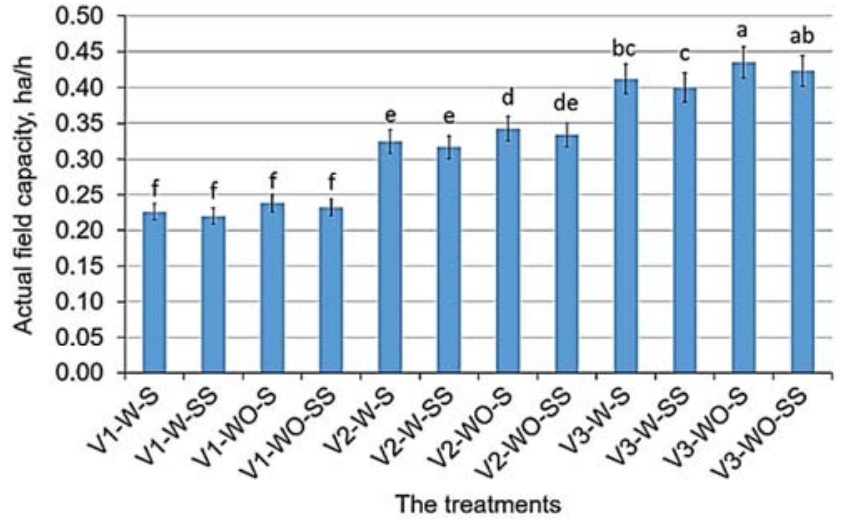

Figure 10. Effect of study treatments ( $V$-forward speed, $W$ - with mulching plastic, S S-laying surface drip irrigation pipes, SS- laying sub-surface drip irrigation pipes and WO- without mulching plastic) on actual field capacity. Values followed by different letters are significantly different at $p<0.05$ according to the LSD test. Error bars show the standard deviation among the repetitions $(n=3)$. LSD for actual field capacity $=0.01412$.

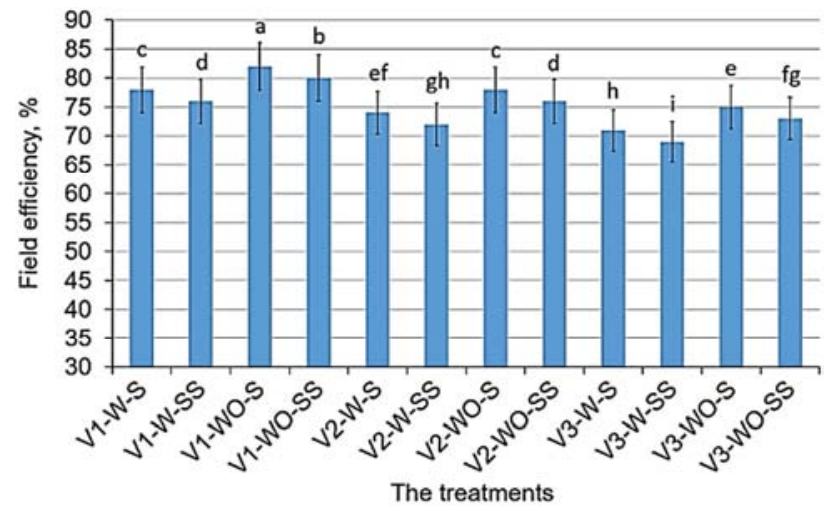

Figure 11. Effect of study treatments ( $V$ - forward speed, $W$ - with mulching plastic, S- laying surface drip irrigation pipes, SS- laying sub-surface drip irrigation pipes and WO- without mulching plastic) on field efficiency. Values followed by different letters are significantly different at $p<0.05$ according to the LSD test. Error bars show the standard deviation among the repetitions $(n=3)$. LSD for field efficiency $=1.45254$.

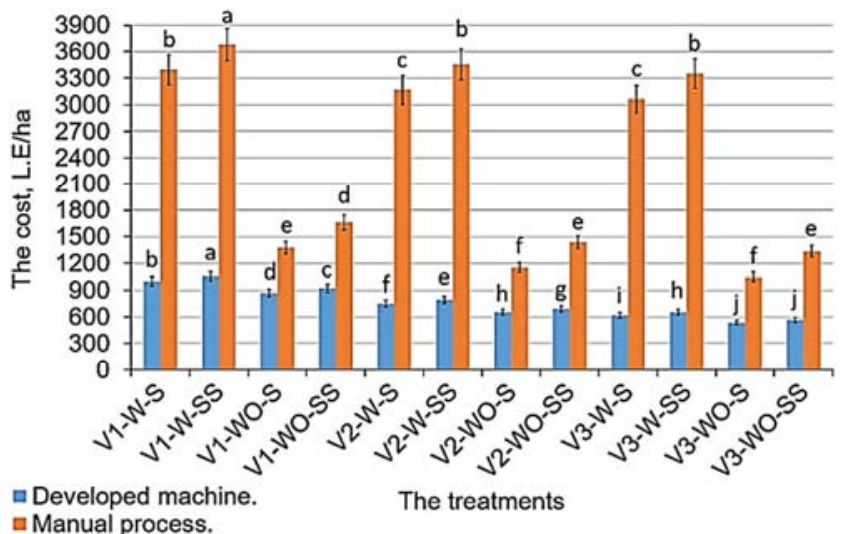

Figure 12. Effect of study treatments (V-forward speed, W- with mulching plastic, S- laying surface drip irrigation pipes, SS- laying sub-surface drip irrigation pipes and WO- without mulching plastic) on the cost of developed machine and manual process. Values followed by different letters are significantly different at $p<0.05$ according to the LSD test. Error bars show the standard deviation among the repetitions $(n=3) . L S D$ for the developed machine cost $=28.3385$ and manual process cost $=113.07$.

\subsection{Effect of Study Treatments on Pulling Force and Fuel Consumption Rate}

As shown in Figures 13 and 14 pulling force (PF) increased about $(9 \%-17 \%)$ and fuel consumption rate (FC) increased about $(8 \%-16 \%)$ when operation speed increased from 2 to 3 and $4 \mathrm{~km} / \mathrm{h}$ respectively. $\mathrm{PF}$ and $\mathrm{FC}$ increased about $10 \%$ and $11 \%$ respectively when laying plastic mulch compared to without laying treatment. Also, PF and FC increased about $3 \%$ and $4 \%$ respectively when laying subsurface drip irrigation pipes compared to lay it on surface.

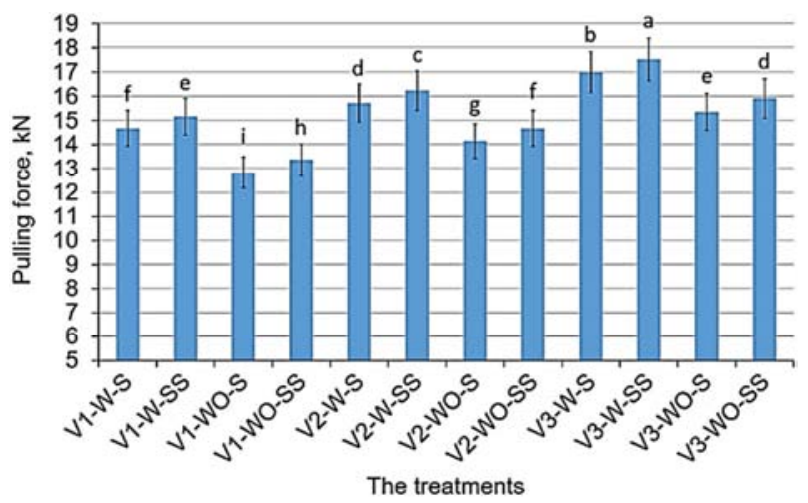

Figure 13. Effect of study treatments ( $V$-forward speed, $W$-with mulching plastic, S- laying surface drip irrigation pipes, SS-laying sub-surface drip irrigation pipes and WO-without mulching plastic) on pulling force. Values followed by different letters are significantly different at $p<0.05$ according to the LSD test. Error bars show the standard deviation among the repetitions $(n=3)$. LSD for pulling force $=0.2273$.

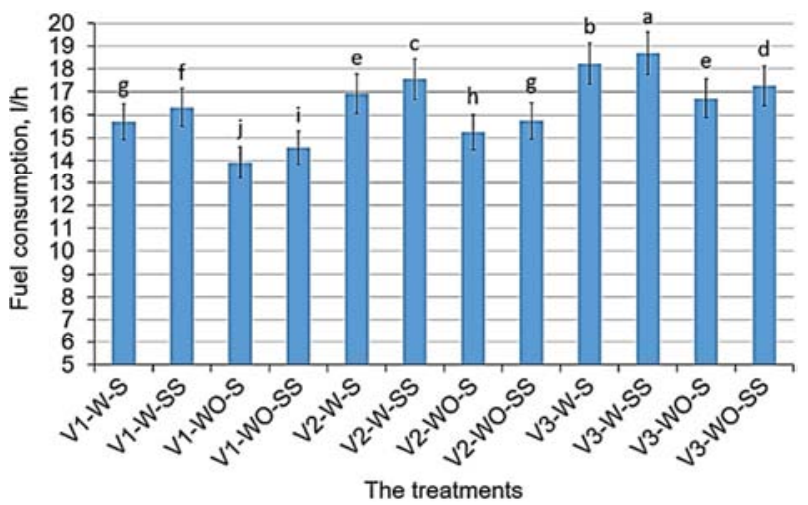

Figure 14. Effect of study treatments ( $V$-forward speed, W-with mulching plastic, $S$ - laying surface drip irrigation pipes, SS-laying sub-surface drip irrigation pipes and WO- without mulching plastic) on fuel consumption rate. Values followed by different letters are significantly different at $p<0.05$ according to the LSD test. Error bars show the standard deviation among the repetitions $(n=3)$. LSD for fuel consumption $=0.1986$.

\subsection{Effect of Study Treatments on Total Water Stored and Water Consumption Use}

Figures 15 and 16 showed that total water stored (TWS) and water consumption use (WCU) decreased when operation speed increased from 2 to 3 and $4 \mathrm{~km} / \mathrm{h}$ about $(2.5 \%-4 \%)$ and $(4 \%-6 \%)$ respectively. These results may be due to the fact that, as operation speed increased the machine efficiency to install raised-bed and laying plastic mulch decreased which caused decreasing water 
stored and water consumption. The results showed too increased in TWS and WCU about $22 \%$ and $23 \%$ respectively when laying plastic mulch compared to without laying plastic mulch. TWS and WCU increased about $12 \%$ and $17 \%$ respectively, when laying sub-surface drip irrigation pipes compared to laying it on surface.

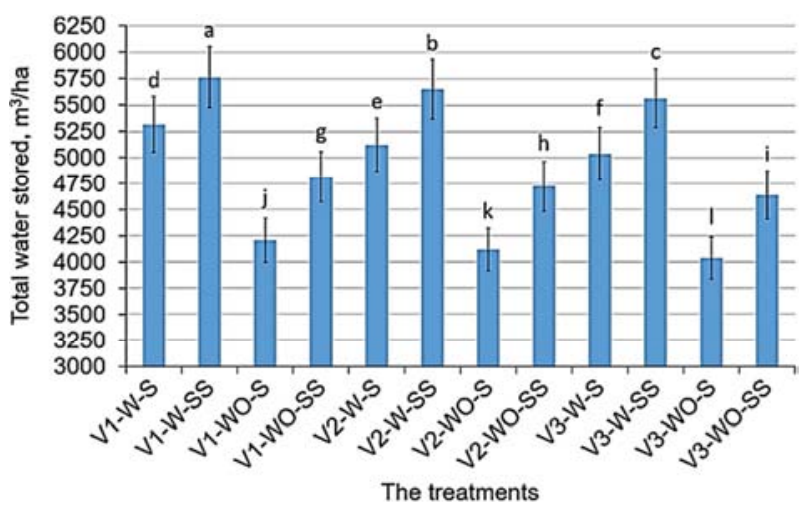

Figure 15. Effect of study treatments ( $V$-forward speed, W-with mulching plastic, S-laying surface drip irrigation pipes, SS-laying sub-surface drip irrigation pipes and WO- without mulching plastic) on total water stored. Values followed by different letters are significantly different at $p<0.05$ according to the LSD test. Error bars show the standard deviation among the repetitions $(n=3)$. $L S D$ for total water stored $=81.465$.

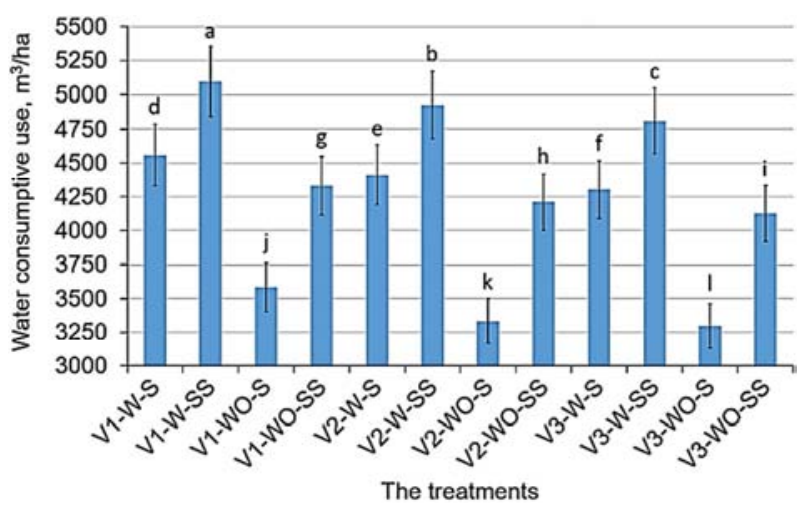

Figure 16. Effect of study treatments ( $V$-forward speed, $W$ - with mulching plastic, S- laying surface drip irrigation pipes, SS- laying sub-surface drip irrigation pipes and WO- without mulching plastic) on water consumption use. Values followed by different letters are significantly different at $p<0.05$ according to the LSD test. Error bars show the standard deviation among the repetitions $(n=3)$. LSD for water consumption use $=15$.

\subsection{Effect of Study Treatments on Water Application Efficiency and Soil Salinity}

Data as shown in Figures 17 and 18 proved that water application efficiency decreased when operation speed increased from 2 to 3 and $4 \mathrm{~km} / \mathrm{h}$ about $2.5 \%$ and $4 \%$ respectively. In addition, soil salinity increased when operation speed increased from 2 to 3 and $4 \mathrm{~km} / \mathrm{h}$ about $9 \%$ and $17 \%$ respectively. On the other hand, water application efficiency increased about $22 \%$ when laying plastic mulch compared to without laying and increased about $12 \%$ when laying sub-surface drip irrigation pipes compared to laying it on surface. Soil salinity decreased about $38 \%$ when laying plastic mulch and about $21 \%$ when laying sub-surface drip irrigation pipes compared to without plastic mulch and laying surface drip pipes respectively.

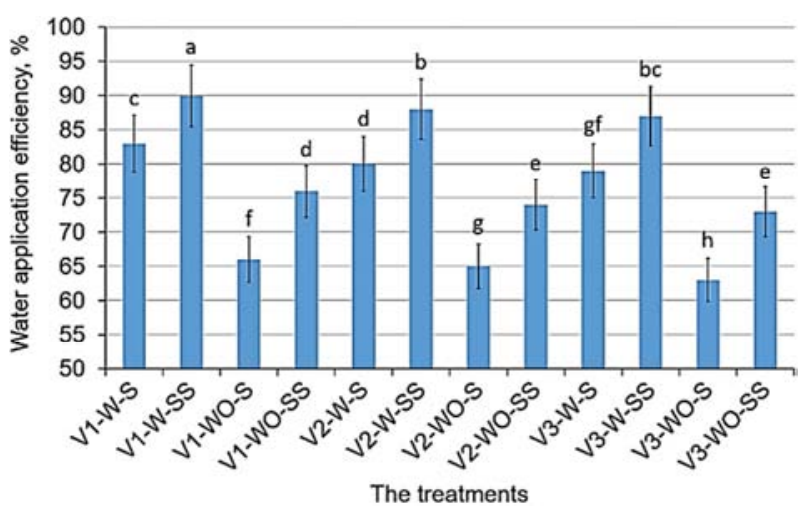

Figure 17. Effect of study treatments ( $V$-forward speed, $W$-with mulching plastic, S- laying surface drip irrigation pipes, SS-laying sub-surface drip irrigation pipes and WO- without mulching plastic) on water application efficiency. Values followed by different letters are significantly different at $p$ $<0.05$ according to the LSD test. Error bars show the standard deviation among the repetitions $(n=3)$. LSD for water application efficiency $=1.4525$.

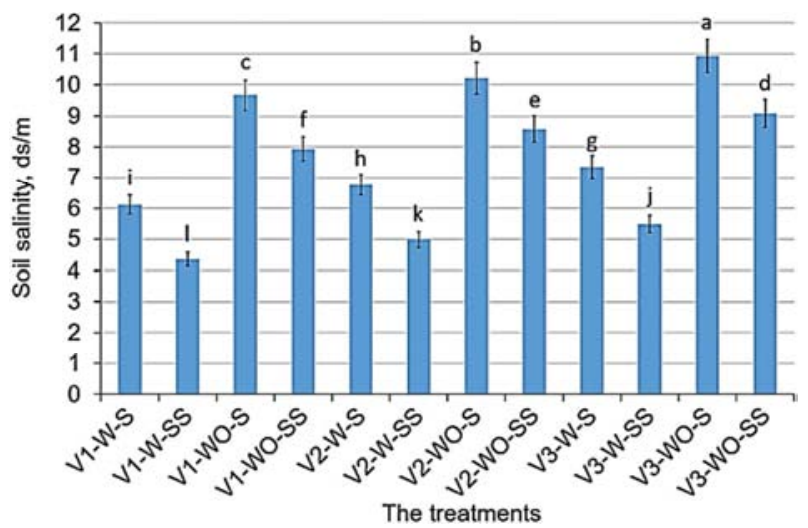

Figure 18. Effect of study treatments ( $V$-forward speed, $W$-with mulching plastic, S-laying surface drip irrigation pipes, SS-laying sub-surface drip irrigation pipes and WO- without mulching plastic) on soil salinity. Values followed by different letters are significantly different at $p<0.05$ according to the LSD test. Error bars show the standard deviation among the repetitions $(n=3)$. LSD for soil salinity $=0.2326$.

\subsection{Effect of Study Treatments on Chilli Yield, Productivity of Irrigation Water and Mulching Efficiency}

Figures 19 and 20 showed that chilli yield (CY) and productivity of irrigation water (PIW) decreased when operation speed increased from 2 to 3 and $4 \mathrm{~km} / \mathrm{h}$ about $(7 \%$ - $14 \%)$ and $(8 \%$ - $14 \%)$ respectively. In addition, increasing of CY and PIW when laying plastic mulch and laying subsurface drip irrigation pipes about $(29 \%-17 \%)$ and $(28 \%-$ $16 \%$ ) respectively, compared to without laying plastic mulch and laying surface drip irrigation pipes. Figure 21 showed that the highest mulching efficiency $96 \%$ at operation speed 2 $\mathrm{km} / \mathrm{h}$ and laying sub-surface drip irrigation pipes. Then $93 \%$ at operation speed $2 \mathrm{~km} / \mathrm{h}$ and laying surface drip irrigation pipes. Then $85 \%$ at operation speed $3 \mathrm{~km} / \mathrm{h}$ and laying subsurface drip irrigation pipes. Then $82 \%$ at operation speed 3 $\mathrm{km} / \mathrm{h}$ and laying surface drip irrigation pipes. Then $70 \%$ at operation speed $4 \mathrm{~km} / \mathrm{h}$ and laying sub-surface drip irrigation pipes. Then $67 \%$ at operation speed $4 \mathrm{~km} / \mathrm{h}$ and laying 
surface drip irrigation pipes. These results may be due to the fact that, as operation speed increased the machine gets less time to collect and cover soil over the edges of plastic as a result, decreased mulching efficiency. Also, when laying plastic mulch with surface drip pipes may be caused injured plastic film and made air pockets under the plastic mulch as a result, decreased mulching efficiency.

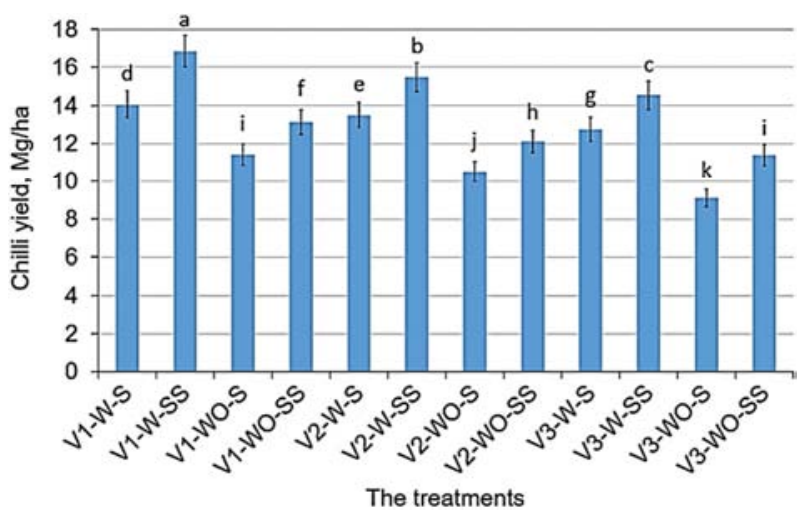

Figure 19. Effect of study treatments ( $V$-forward speed, W-with mulching plastic, S-laying surface drip irrigation pipes, SS-laying sub-surface drip irrigation pipes and WO- without mulching plastic) on chilli yield. Values followed by different letters are significantly different at $p<0.05$ according to the LSD test. Error bars show the standard deviation among the repetitions $(n=3)$. LSD for chilli yield $=0.1158$.

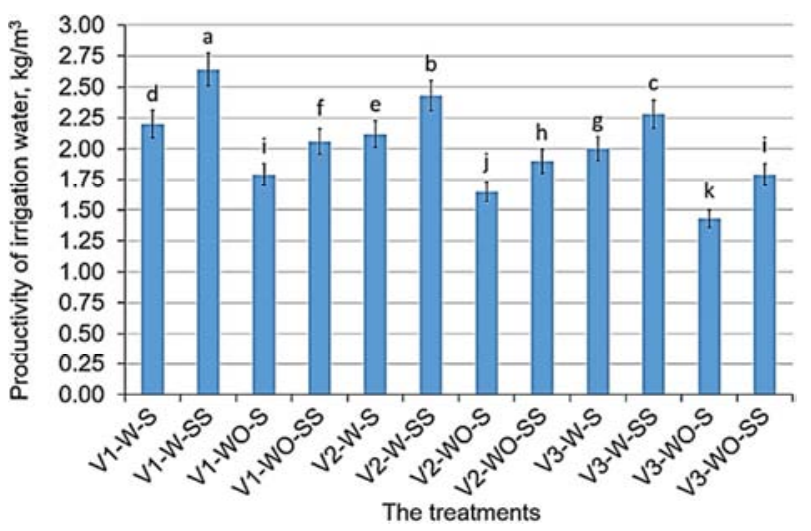

Figure 20. Effect of study treatments ( $V$-forward speed, $W$-with mulching plastic, S-laying surface drip irrigation pipes, SS-laying sub-surface drip irrigation pipes and WO- without mulching plastic) on productivity of irrigation water. Values followed by different letters are significantly different at $p<0.05$ according to the LSD test. Error bars show the standard deviation among the repetitions $(n=3)$. LSD for productivity of irrigation water $=0.0543$.

\subsection{Effect of Forward Speed on Width and Thickness of Soil Cover for Plastic Mulch Edges}

The effect of operation speed on width and thickness of soil cover for plastic mulch edges showed in Figure 22. With increasing in operation speed from 2 to $4 \mathrm{~km} / \mathrm{h}$, the width of soil cover decreased from $23.63 \mathrm{~cm}$ to $13.58 \mathrm{~cm}$ and the thickness of soil cover decreased from $17.51 \mathrm{~cm}$ to $8.83 \mathrm{~cm}$. These results may be due to the fact that, the machine gets less time to collect and cover soil over the edges of plastic sheet as speed increases.

\subsection{Effect of Forward Speed on Width and Height of Raised-Bed}

Results in Figure 23 showed that with increasing in operation speed from 2 to $4 \mathrm{~km} / \mathrm{h}$, the raised-bed width decreased from $88.71 \mathrm{~cm}$ to $73.85 \mathrm{~cm}$ and the height of raised-bed decreased from $29.2 \mathrm{~cm}$ to $23.7 \mathrm{~cm}$. These results may be due to the fact that, the machine gets less time to gather soil on the field as speed increases.

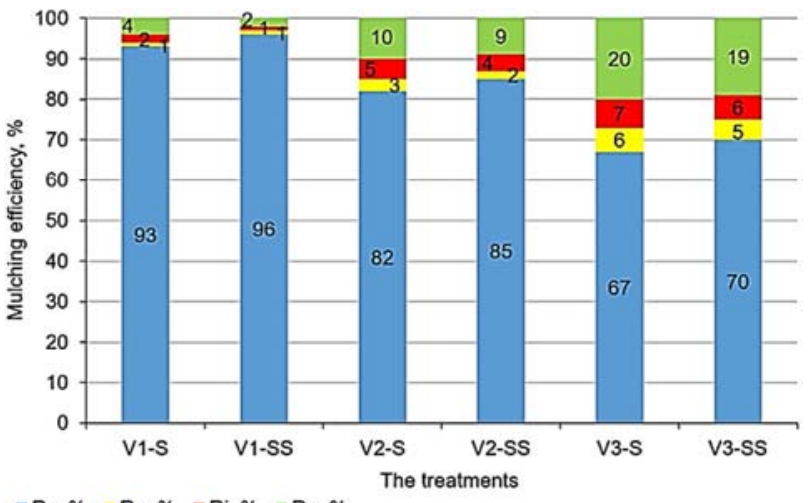

aRc, \% $=\mathrm{Ru}, \% \quad$ =Ri, \% $\quad$ Rp, \%

Figure 21. Effect of study treatments ( $V$-forward speed, $S$ - laying surface drip irrigation pipes and SS- laying sub-surface drip irrigation pipes) on mulching efficiency. Where, Rc-the correct covered mulched film in length of $10 \mathrm{~m}, \mathrm{Ru}$ - the un-covered mulched film edge length in $10 \mathrm{~m}$, Ri- the injured mulched film in10 length $m$ and Rp-the air pockets under the film in length of $10 \mathrm{~m}$.

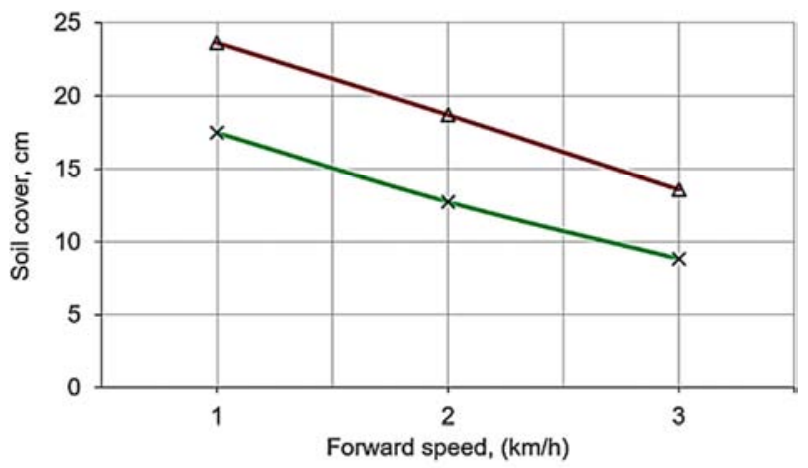

$\star$ Width of soil cover, $\mathrm{cm} *$ Thickness of soil cover, $\mathrm{cm}$

Figure 22. Effect of forward speed on width and thickness of soil cover.

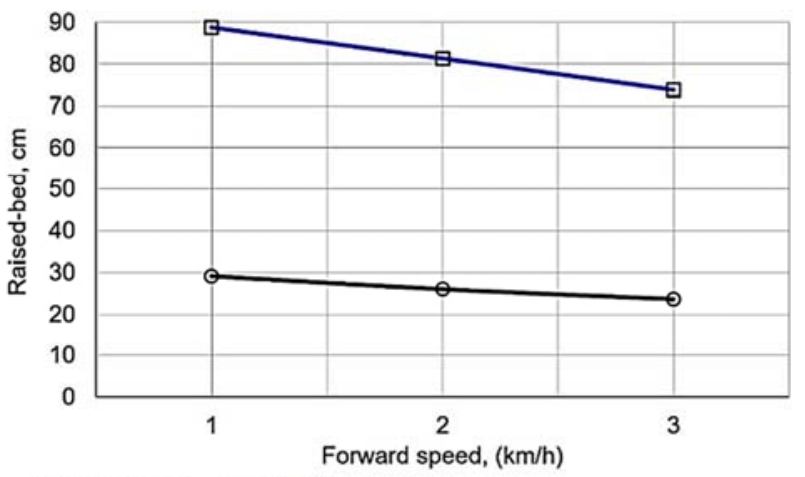

$\Theta$ Height of bed, $\mathrm{cm} \quad \boxminus$ Width of bed, $\mathrm{cm}$

Figure 23. Effect of forward speed on height and width of raised-bed. 


\section{Conclusion}

A wide ridge (raised-bed) equipment was developed to mechanize the conventional plastic mulching and laying drip irrigation pipes (surface and subsurface) which, worked to facilitate the implementation of this method, saves time, labor and increases timeliness of operation. By using plastic mulch, and sub-surface drip irrigation pipes maintain the soil moisture and increased chilli yield. From the study results, found that as forward speed increased from 2 to $4 \mathrm{~km} / \mathrm{h}$ pulling force and fuel consumption rate increased about $17 \%$ and $16 \%$ respectively. For installing raised-bed and laying both plastic mulch and drip irrigation pipes, $2 \mathrm{~km} / \mathrm{h}$ speed is found to be better. Using plastic mulch and sub-surface drip irrigation pipes achieved the highest percentage of productivity of irrigation water $28 \%$ and yield of chilli crop $29 \%$ while, achieved the lowest percentage of soil salinity $38 \%$ compared to not using plastic mulch and using surface drip irrigation pipes. On the other hand, providing such a mulching machine is surely decrease the mulching costs about $68 \%$ compared to manual mulching. Thus, the plastic mulch-laying machine may give immediate solution for the advancement in the cultivating methods in agricultural sector

\section{References}

[1] Scott, G. and Gilead, D. 1995. Degradable polymers: principles and applications. Kluwer Academic Chapman and Hall.

[2] Joel, F. R. 1995. Polymer science and technology: introduction to polymer science. 3rd Edn. Prentice Hall, Upper Saddle River, p: 4-9.

[3] Mane, V. S. and Urmani N. K. 1981. Application of mulch at various stages of crop growth under dry land condition. Indian J. Agron., 26: 1-6.

[4] Bartolo, M. 1996. Early Cantaloupe Production in the Arkansas Valley, Arkansas Valley Research Center Annual Report, Rocky Ford, Colorado State University.

[5] Schonbeck M. W. and Evanylo G. K. 1998. Effect of mulches on soil properties and tomato production 1 . Soil temperature, soil moisture and marketable yield. Journal of sustainable Agriculture 13: 55-81.

[6] Strizaker, R. J., Sutton, B. G. and Collis-George, N. 1989. Sustainable system of soil management in vegetable production. Acta. Hort., 246, 81-84.

[7] Jones, T. L., Jones, U. S. and Ezeli, D. O. 1977. Effect of irrigation and plastic mulch on properties of troup sand on yield of "water tomato". J. Amer. Soc. Hort. Sci., 102, 27-35.

[8] Singh, P. N., Joshi, B. P. and Singh, G. 1988. Effect of mulch on moisture conservation, irrigation requirement and yield of potato. Indian J. Agron., 32, 451-451.

[9] Lal, R. 1989. Conservation tillage for suitable agriculture: tropics versus temperate environments. Adv. Agron., 42, 147151 .
[10] Mohler, C. L. and Calloway, M. B. 1992. Effect of tillage and mulch on the emergence and survival of weeds in sweet corn. J. Appl. Ecol., 29, 21-34.

[11] Nagalakshmi, S., Palanisamy, D., Eswaran, S. and Sreenarayanan, V. V. 2002. Influence of plastic mulching on chilli yield and economics. South Indian Hort., 50, 262-265.

[12] Greenly K. M and Rakow, D. A. 1995. The effect of wood mulch type and depth on weed and tree growth and certain soil parameters. J Arboric. 21: 225-225.

[13] Gleason M. L. and Iles, J. K. 1998. The proper use of organic mulch offers numerous benefits for your woody landscape plants. Am Nurseryman. 187: 24-31.

[14] Rathinasabapathi B, Ferguson, J. and Gal, M. 2005. Evaluation of allelopathic potential of wood chips for weed suppression in horticultural production systems. Hort Science 40: 711-713.

[15] Chalker-Scott, L. 2007. Impact of mulches on landscape plants and the environment a review. J Environ Hortic. 25: 239.

[16] Hanada, T. 1991. The effect of mulching and row covers on vegetable production. Kyoto: Food and Fertilizer Technology Center.

[17] Lamont, W. 2004a. Plastic mulches. In: Lamont W (ed) Production of vegetables, strawberries, and cut flowers using plasticulture. Natural Resource, Agriculture, and Engineering Service (NRAES), Ithaca.

[18] Ashrafuzzaman, M. Abdul Halim, Mohd Razi Ismail, Shahidullah, S. M. and Kalamgir Hossain, M. 2006. Effect of plastic mulch on growth and yield of chilli (Capsicum annuum L.) Brazilian archives of biology and technology an International Journal, 54 (2): 321-330, March-April 2011.

[19] Chakraborty, D., Nagarajan, S., Aggarwal, P., Gupta, V. K., Tomar, R. K., Garg, R. N., Sahoo, R. N., Sarkar, A., Chopra, U. K., Sarma, K. S. S., Kalra, N. 2008. Effect of mulching on soil and plant water status, and the growth and yield of wheat (Triticum aestivum L.) in a semiarid environment. Agric. Water Manag. 95, 1323-1334.

[20] Krishnamurthy, L., Vadez, V., Jyotsna, D., Serraj, M., Nigam, R., Sheshshayee, S. and Aruna, S. 2007. Variation in transpiration efficiency and its related traits in a groundnut (Arachis hypogaea L.) mapping population. Field Crop Res. 103: 189-197.

[21] Bilck A. P., Grossmann, M. and Yamashita, F. 2010. Biodegradable mulch films for strawberry production. Polymer testing. Vol. (29), pp 471- 476.

[22] Chakraborty D., Garg, R. N. and Tomar, R. K. 2010. Synthetic and organic mulching and nitrogen effect on winter wheat (Triticum aestivum L.) in semi-arid environment. Agricultural water management 97: 738-748.

[23] Kaushal, A., Patole, R., and Singh, K. G. 2012. Drip irrigation in sugarcane: A review, Journal of Agriculture Review 33: 211-219.

[24] Aragüés R., Medina, E. T., Martínez-Cob, A. and Faci, J. M. 2014. Effects of deficit irrigation strategies on soil salinization and sodification in a semiarid drip-irrigated peach orchard. Agricultural Water Management 142: 1-9. 
[25] Korpela A., Ahokas, J., Asikainen, J., Pitkänen, M., Vikman, M., Kujanpää, M., Mikkola, H. and Tamminen, A. 2014. Development of paper mulches. AGRIPAP-Research report VTT-R- 00555-14. University of Helsinki.

[26] Singh K. G., Sharda, R. K., Rudra, R. P. and Khan, A. A. 2014. Mechanization of mulch laying process-A boon in sustaining global agricultural production, 45 (4).

[27] Chaurasiya P. C. and Sahu, G. D. 2015. Effect of different type of mulch, fertigation and drip irrigation in chilli on open field condition. (unpub.), I. G. K. V., Raipur.

[28] Cabrera, J. R., Zotarelli, L., Dukes, M. D., Rowland, D. L. and Sargent, S. A. 2016. Soil moisture distribution under drip irrigation and seepage for potato production. Agricultural Water Management. 169: 183-192.

[29] Siddesh M. and Veerangouda, M. 2017. Development and evaluation of tractor operated plastic mulch laying equipment. International Journal of Agricultural Engineering, V. (10) I. (2), 374-378.

[30] Gowd C. M. S. and Prasad, B. D. 2017. Design and development of plastic mulch laying machine in agriculture, IJTIMES, AP, India, 3 (11): 97-100.

[31] Magdum S. S., Patil, S. B. and Mulla, L. B. 2017. Automatic mulch paper laying machine for agricultural application, ISSN 2230-9659, 13 (01): 241-244.

[32] Berger, S., Kim, Y., Kettering, J. and Gebauer, G. 2013. Plastic mulching in agriculture Friend or foe of $\mathrm{N}_{2} \mathrm{O}$ emissions. Agric. Ecosyst. Environ. 167, 43-51.

[33] Bandopadhyay, S., Martin-Closas, L., Pelacho, A. M., and De Bruyn, J. M. 2018. Biodegradable plastic mulch films: Impacts on soil microbial communities and ecosystem functions. Front. Microbiol. 9, 819.

[34] Ma, D., Chen, L., Qu, H., Wang, Y., Misselbrook, T. and Jiang, R. 2018. Impacts of plastic film mulching on crop yields, soil water, nitrate, and organic carbon in Northwestern China: A meta-analysis. Agric. Water Manag. 202, 166-173.

[35] Sumant, R., Shetty, P. and Sajjan, S. C. 2020. Design and
Development of Tractor Operated Plastic Mulch Laying Machine. Journal of Mechanical Robotics. V. (5), I. (1) P. (1619).

[36] Nones, Raymond 2010. Raised-Bed Vegetable Gardening Made Simple. Countryman Press. Retrieved March 2, 2012. ISBN 978-0-88150-896-3

[37] Ahmad, R. N., and Mahmood, N. 2005. Impact of raised bed technology on water productivity and lodging of wheat. Pakistan Journal of Water Resources, 9 (2), 29-32.

[38] Ahmad, I. M., Qubal, B., Ahmad, G. and Shah, N. H. 2009. Maize yield, plant tissue and residual soil $\mathrm{N}$ as affected by nitrogen management and tillage system. J. Agric. Biol. Sci. 1 (1), 19-29.

[39] Bakker, D., Hamilton, M., Hetherington, G. J. and Spann, R. 2010. Salinity dynamics and the potential for improvement of water logged and saline land in a Mediterranean climate using permanent raised beds. Soil Tillage Res. 110 (1), 8-24.

[40] Andreas P. S. and Karen, F. 2002. Crop Water Requirements and Irrigation Scheduling; Irrigation Manual Module 4.

[41] Kepner, R. A., Bainer, R. and Barger, E. L. 1978. Principles of farm machinery. Third Edition. A VI Publishing Company, Inc. Westport, Connecticut. U.S.A. P: 186.

[42] James, L. G. 1988. Principles of farm irrigation system design. John Willey \& Sons (ed.), New York, pp. 543.

[43] Hansen, V. W., Israelsen, O. W. and Stringharm, G. E. 1979. Irrigation principles and practices. $9^{\text {th }}$ ed., John Willey and Sons Inc., New York, USA.

[44] Israelsen, O. W. and Hansen, V. E. 1962. Irrigation principles and practices. $3^{\text {rd }}$ Ed. John Willey and Sons Inc., New York.

[45] Ali, M. H., Hoque, M. R., Hassan, A. A. and khair, A. 2007. Effects of deficit irrigation on yield, water productivity and economic returns of wheat. Agricultural water management, 92 (3): 151-161.

[46] Oida, A. 1997. Using personal computer for agricultural machinery management. Kyoto University. Japan. JICA publishing. 